\title{
New and poorly known Oriental Chrysomelidae (Insecta: Coleoptera) from the collection of Erfurt Museum
}

\section{Новые и мало известные ориентальные Chrysomelidae (Insecta: Coleoptera) из комлекщии музея Эрфурта}

\author{
L.N. Medvedev

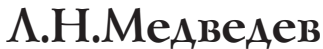

Institute for Problems of Ecology and Evolution, Russian Academy of Sciences, Leninsky prospect 33, Moscow 119071, Russia.
Институт проблем экологии и эволюции РАН, Ленинский проспект 33, Москва 119071, Россия.

KEY WORDS: Chrysomelidae, new species, new localities, taxonomical and ecological notes, Northern Vietnam, Thailand, China.

КЛЮЧЕВЫЕ СЛОВА: Chrysomelidae, новые виды, новые местонахождения, таксономические и экологические заметки, Северный Вьетнам, Таиланд, Китай.

ABSTRACT. Six new species Cryptocephalus duongi, Massiea bacboensis, Chrysolampra weigeli, Colaspoides ventralis, Hyphaenia weigeli, Dercetina weigeli spp.n. are described from the Northern Vietnam and Thailand. A few species are firstly recorded for Vietnam and China.

РЕЗЮМЕ. Описываются 6 новых для науки видов Cryptocephalus duongi, Massiea bacboensis, Chrysolampra weigeli, Colaspoides ventralis, Hyphaenia weigeli, Dercetina weigeli spp.n. из Северного Вьетнама и Таиланда. Несколько видов впервые указаны для Вьетнама и Китая.

\section{Introduction}

Thanks to amiability of Dr. Matthias Hartmann I had a good opportunity to study new materials from Erfurt Museum, collected in Northern Vietnam, Thailand and China. As a result of this study six species are described as new for science, one species is firstly found in Vietnam and two species of poorly studied genus Geinella Strand, 1935 are recorded and discussed.

Next abbreviations are used for depository places of new species: MNE — Erfurt Museum, Erfurt, BRD; LM - author's collection, Moscow, Russia.

Taxonomical part

Subfamily Cryptocephalinae

Cryptocephalus (s. str.) duongi $\mathbf{s p .} \mathbf{n}$.

Fig. 1.

MATERIAL. Holotype, $\sigma^{7}$ : Vietnam bor., Pr. Hoang Lien Son, Sa Pa, VI.1990, leg. Duong Tat Tu (LM). Paratype: Vietnam, Bac
Gang Prov., Tay Yen Tu Nat. Res., 6 km, SW Than Son, N 21 10'83”, E $106^{\circ} 43$ '43”, 200 m, KS/LFF, 18-21.V.2015, leg. A. Weigel, 1 व' (MNE)

DESCRIPTION. Fulvous, antennae except basal segment, basal margin of prothorax and elytra, tibiae and tarsi black.

Head punctate on vertex and middle of frons, interocular space as wide as length of basal antennal segment/ Antennae reach middle of elytra, thin, proportions of segments are as 11-3-6-8-8-11-11-10-10-10-10, preapical segments about 5 times as long as wide. Prothorax 1/5 times as wide as long, broadest at base and strongly narrowed anteriorly, lateral margins almost straight, surface strongly convex, shining and impunctate, basal margin finely denticulate. Scutellum cordiform, impunctate. Elytra as long as wide, with regular rows of punctures, except humeral row, which is interrupted and confused, interspaces more or less convex, especially on sides, impunctate. Pygidium convex, distinctly punctate, broadly rounded on apex. Segment 1 of anterior tarsi of male elongate and moderately widened. Aedeagus - Fig. 1.

Length of body $3.5-3.7 \mathrm{~mm}$.

DIAGNOSIS. Near C. punctobrunnescens Pic, 1927 from Northern Vietnam, differs with less transverse prothorax and apex of aedeagus broadly triangular, not subtruncate.

ETYMOLOGY. Species is named after its collector.

\section{Subfamily Eumolpinae}

Massiea bacboensis L. Medevedev, sp.n. Fig. 2.

MATERIAL. Holotype, $\sigma^{7}$ : N Vietnam, Lao Cai Prov, Hoang Lien NP, Tram Ton, N 22²1'20', E 10346'51', 1800-2500 m, 15.V.2015, leg. A. Weigel (MNE). Paratypes: same locality and date, $2 \sigma^{\top} \sigma^{\prime}, 2$ O (MNE, 1 ex. - LM); same locality, N 22 21'19.7", E 10348'51.3", 1800-2500 m, 13-16.V.2015, 10 ex, leg. A. Scale (MNE, 2 ex. - LM).

DESCRIPTION. Body metallic green with purple lateral margin of elytra, labrum, the second and third antennal segments fulvous, sometimes prothorax with aeneous tint.

How to cite this article: Medvedev L.N. 2018. New and poorly known Oriental Chrysomelidae (Insecta: Coleoptera) from the collection of Erfurt Museum // Russian Entomol. J. Vol.27. No.3. P.281-284. doi: 10.15298/ rusentj.27.3.07 
Body elongate, 2.2-2.4 times as long as wide. Head with deep and moderately dense punctures, vertex with longitudinal groove, anterior margin of clypeus straight. Antennae thin, reach middle of elytra, proportions of segments are as 6$3-8-6-8-8-10-9-10-9-10$, preapical segments about thrice as long as wide. Prothorax as long as wide, broadest in anterior third, but lateral margins almost straight, surface shining, with rather large sparse punctures, especially along anterior and posterior margins, with oblique impression on each side at basal quarter. Scutellum narrow, almost parallel-sided with truncate apex, microsculptured. Elytra twice as long as wide, parallel-sided with rounded apices, surface shining, densely punctate (punctures twice larger than on prothorax), interspaces mostly flat and comparable with diameter of punctures. Segment 1 of anterior and mid tarsi of male widened, this segment 1.5 times as long as wide on anterior and twice as long as wide on mid tarsi. Aedeagus (Fig. 2) with acute apex and evenly convex underside.

Length of male $6.7-7.1 \mathrm{~mm}$, of females $7.2-7.4 \mathrm{~mm}$

DIAGNOSIS. Near M. cylindrica Chujo,1938, from China, differs with bicolor and more elongate, parallel-sided elytra.

ETYMOLOGY. A name is connected with a region of the species distribution.

\section{Chrysolampra weigeli L. Medevedev, sp.n.}

Fig. 3.

MATERIAL. Holotype, $\sigma^{7}$ : N Vietnam, Cao Bong Prov., vic. Tinh Tue, Song Dong, Nui Pia Oac Nature Res, $22^{\circ} 37.55^{\prime} \mathrm{N}$, $105^{\circ} 52.98^{\prime}$ E, 09-15. V.2014, 850-1300 m, by light, leg. A. Weigel (MNE).

DESCRIPTION. Metallic green, antennae fulvous with 6 apical segments piceous, labrum fulvous.

Body elongate, twice as long as wide. Head distinctly punctate, vertex transversely rugose in middle, with deep longitudinal groove, clypeus with straight anterior margin. Antennae thin and long, reach apical slope of elytra, proportions of segments are as 8-2-9-9-11-15-18-18-17-17-15, preapical segments about 8 times as long as wide. Prothorax
1.6 timnes as wide as long, broadest behind middle, lateral margins feebly arcuate, surface microsculptured, not large and rather sparse punctures. Scutellum trapeziform with rounded apex, microsculptured. Elytra 1.6 times as long as wide, with feeble basal convexity, densely and confusedly punctate in inner half, with rugosities in outer half, interspaces very finely microsculptured. Pygidium punctate, central furrow broad and sharp. Propleurae sparsely punctate. All femora not toothed, segment 1 of fore and mid tarsi strongly widened, much broader than the third segment. Aedeagus (Fig. 3) without any sculpture on underside.

Length of body $8.5 \mathrm{~mm}$.

DIAGNOSIS. Near Ch. cyanea Lefevre, 1884 from South China and North Vietnam, differs with color, thin antennae, rugose elytra and form of aedeagus. This new species is very alike at Ch. splendens Baly, 1859 in sculpture of upperside and form of aedeagus [Medvedev, 2006], but differs with unarmed anterior femora.

ETYMOLOGY. Species is named after its collector.

\section{Colaspoides ventralis L. Medevedev, sp.n.}

Figs 4, 6

MATERIAL. Holotype, $O^{7}$ : THA[iland], Phitsanulok, $45 \mathrm{~km}$, E. Phit-sanluok. Thung, $16^{\circ} 51^{\prime} 18^{\prime \prime} \mathrm{N} 100^{\circ} 40^{\prime} 19^{\prime \prime} \mathrm{E}, 155 \mathrm{~m}$, 06.05.2012, leg. E. u. J. Huttinger (NME). Paratype: same locality and date, 2 우 (NME, LM)

DESCRIPTION. Upperside metallic green, underside metallic blue (or fulvous in one not matured female), labrum, palpi, antennae (with more or less darkened apical segments) and legs fulvous. Body ovate. Head punctate, more feebly on clypeus, with central groove on vertex. Antennae thin, reach middle of elytra, segments $3-11$ about 5 times as long as wide. Prothorax twice as wide as long, widest behind middle, with acute hind angles, surface shining, finely and sparsely punctate. Elytra 1.45 times as long as wide, strongly and densely, but not rugosely punctate, with a few rows on apical slope. Pygidium densely punctate, its furrow parallel-sided, without ridge on bottom. Propleurae impunctate, shining. Abdomen not serrate on sides of sternites 4 and 5, modified in

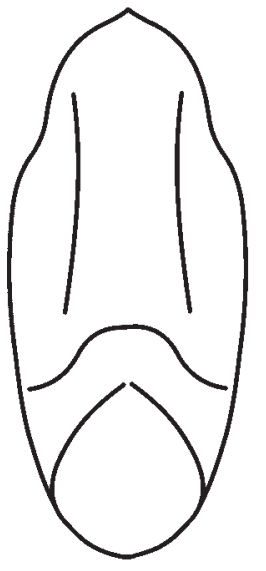

1

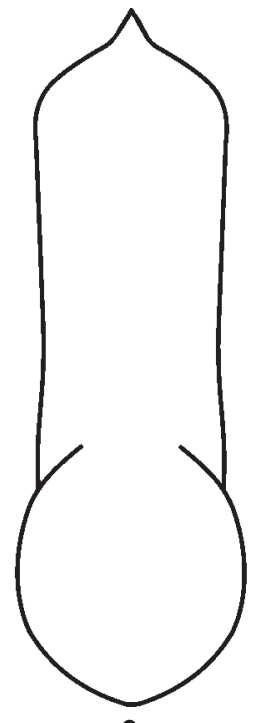

2

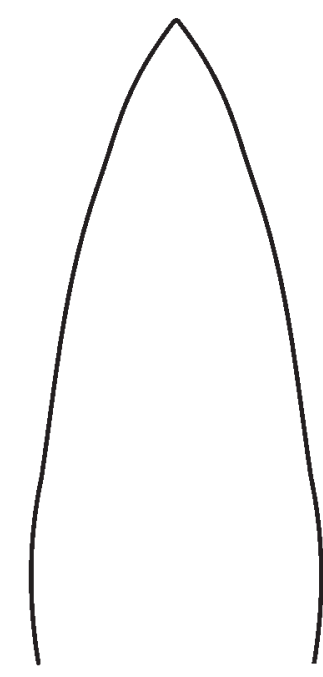

3

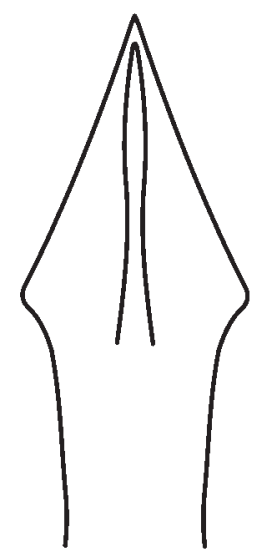

4

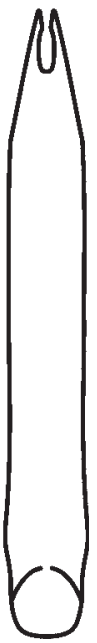

5

Figs 1-5. Aedeagus, ventral view: 1 - Cryptocephalus duongi sp.n.; 2 - Massiea bacboensis sp.n.; 3 - Chrysolampra weigeli sp.n.; 4 - Colaspoides ventralis sp.n.; 5 - Hyphaenia weigeli sp.n..

Рис. 1-5. Эдеагус снизу: 1 - Cryptocephalus duongi sp.n.; 2 - Massiea bacboensis sp.n.; 3 - Chrysolampra weigeli sp.n.; 4 Colaspoides ventralis sp.n.; 5 - Hyphaenia weigeli sp.n.. 
male: the $4^{\text {th }}$ sternite with sharp longitudinal ridge in middle, sternites 2 and 3 with dense brushes; in female abdomen simple, the $5^{\text {th }}$ sternite emarginated on apex. Anterior femora with large acute tooth on underside before middle, hind femora with acute tooth placed near apex and directed to apex. Segment 1 of fore and mid tarsi elongate in male. Aedeagus - Fig. 4, spermatheca - Fig.6.

Length of male $5.0 \mathrm{~mm}$, of females $4.5-4.7 \mathrm{~mm}$.

DIAGNOSIS. Near C. chapuisi L. Medvedev, 2003 from Thailand, included in the artificial group 4 [Medvedev, 2003], but differs in having in male a complicate armament of abdomen, partly remembered C. costalis L. Medvedev, 2003 from the group 6 in the same publication.

ETYMOLOGY. Connected with armament of abdomen in male.

\section{Subfamily Galerucinae}

Hyphaenia weigeli L. Medevedev, sp.n.

\section{Fig. 5.}

MATERIAL. Holotype, $O^{\top}$ : N Vietnam, Lao Cai Prov, Hoang Lien NP, Tram Ton, N 22²1'197", E 10346'513", 1800-2050 m, 13-16.V.2015, leg. A. Weigel (MNE). Paratypes: same locality and date, 2 ex. (MNE, LM); - same locality and date, 1 ex., leg. A. Scale (MNE).

DESCRIPTION. Metallic blue, antennae black with fulvous basal segment, underside blackish blue, legs fulvous with apices of tibiae and tarsi black.

Body elongate, parallel-sided. Head impunctate, microsculptured, clypeus convex with impressions, its anterior margin feebly biarcuate, frontal tubercles transverse and produced between antennal bases. Antennae thin and long, a little longer than body, segments 3-11 with erect hairs, proportions of segments are as 12-3-10-14-15-15-15-13-1311-13, preapical segments about $4-5$ times as long as wide. Prothorax 1.1 times as wide as long, broadest in anterior third, lateral margins feebly arcuate, surface microsculptured, with punctures only near base, its transverse impression deeper on sides. Scutellum triangular with rounded apex, convex, microsculptured. Elytra twice as long as wide, very densely punctate and microsculptured, with 6-7 irregular and low ribs. Aedeagus - Fig. 5.

Length of body $5.7-6.4 \mathrm{~mm}$.

DIAGNOSIS. Near H. elongata Kimoto, 1989, but body much larger and legs fulvous with darkened tarsi.

ETYMOLOGY. Species is named after its collector.
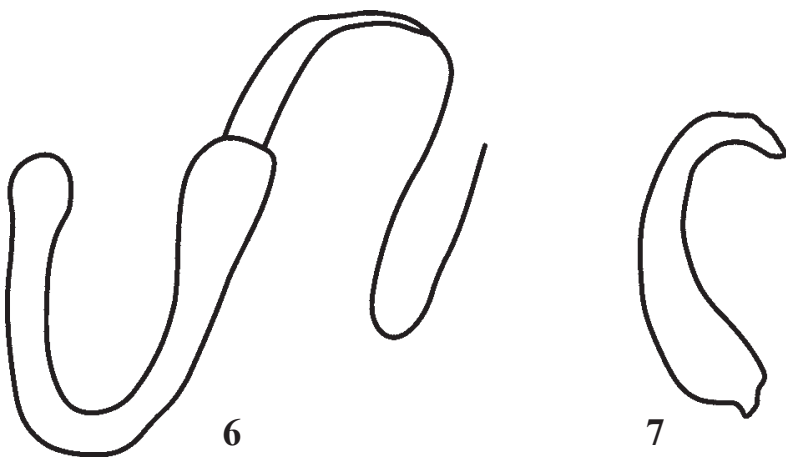

Figs 6-7. Spermatheca: 6 - Colaspoides ventralis sp.n.; 7 Hyphasis fedorenkoi.

Рис. 6-7. Сперматека: 6 - Colaspoides ventralis sp.n.; 7 Hyphasis fedorenkoi.

\section{Dercetina weigeli L. Medevedev, sp.n.}

Fig. 8.

MATERIAL. Holotype, $0^{7}$ : N. Vietnam, Lao Cai Prov., Hoang Lien NP, Ban Khoang, N 2222'78”, E 1034'64”, 2000 m, 15.V.2015, leg. A. Weigel (NME).

DESCRIPTION. Reddish fulvous, elytra with large pale flavous spot in apical half (Fig, 8), tibiae and tarsi blackish. Body elongate, slightly widened to behind, twice as long as wide. Clypeus and interantennal space distinctly punctate, frontal tubercles transverse, sharply delimited posteriorly, vertex very finely punctate, deeply grooved just behind frontal tubercles. Antennae thin, reach apical slope of elytra, proportions of segments are as 11-3-7-15-14-13-13-10-1010-12, preapical segments about 5 times as long as wide. Prothorax 2.3 times as wide as long, broadest in anterior third, lateral margins feebly arcuate, anterior angles produced and acute, posterior angles distinct, surface finely punctate, with traces of impressions on each side. Scutellum triangular, convex and impunctate. Elytra 1.6 times as long as wide, with feeble basal convexity, finely and densely punctate, with narrow shining interspaces.

Length of body $7.8 \mathrm{~mm}$.

DIAGNOSIS. This species differs well from all species of China and Indochina with unusual color of upperside.

ETYMOLOGY. Named after its collector.

\section{New localities}

\section{Subfamily Eumolpinae \\ Aulacia laeta L. Medvedev, 2004}

MATERIAL. Malaysia W., Kelantan, 90 km N of Gua Musang, Mt. Basor, Kampong Kubur Datu, 1700 m, 1.III-21.III.2015, 6 오. leg. Petr Cechovsky (NME, 2 ex. - LM).

REMARK. All specimens are entirely fulvous, only 6 apical antennal segments more or less darkened, but spermathecal is exactly same, as in typical $A$. laeta L. Medvedev.

\section{Aulacia cechovskyi L. Medvedev, 2016}

MATERIAL. Malaysia W., Kelantan, $90 \mathrm{~km} \mathrm{~N}$ of Gua Musang, Mt. Basor, Kampong Kubur Datu, 1700 m, 1.III-21.III.2015, 2 ex., leg. Petr Cechovsky (LM).

REMARK. The description of this species was based on single female. Now I received the other specimen with the same label and date as a holotype. Practically it might be

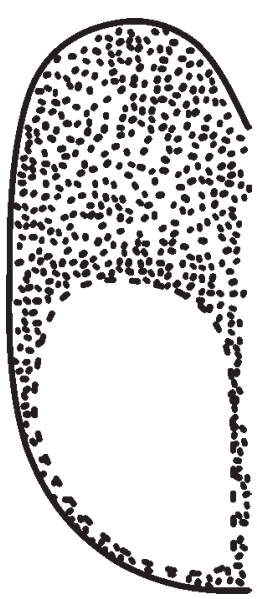

Fig. 8. Dercetina weigeli sp.n., pattern of elytron. Рис. 8. Dercetina weigeli sp.n., рисунок надкрылий. 
accepted as a paratype, because it is entirely identical with a holotype.

\section{Subfamily Chrysomelinae}

Plagiosterna adamsi (Baly, 1884)

MATERIAL. N. Vietnam, Lao Cai Prov., Hoang Lian NP, Trom Tan, N 22 $21.19^{\prime}$, E 10346.51', 1800-2050 m, 13-16.V.2015, leg. A. Weigel, 2 ex. (NME); N. Vietnam, Lao Cai Prov., Hoang Lian NP, Bon Khoang, N 22 22.78', E 10347.64', 2000 m, 15.V.2015, leg. A. Weigel, 2 ex. (NME, LM).

REMARK. Was known from Nepal, North India and China, firstly found in Vietnam.

\section{Subfamily Galerucinae}

Geinella nila brevicollis Chen \& Jiang, 1981

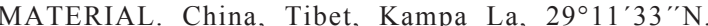
90³7'16"E, 27.VII.2015, 4820 m, leg. J. Schmid, 1 male (MNE).

REMARK. Two subspecies of this species were proposed [Chen, Jiang, 1931]. This specimen is transitional between G. nila brevicollis Chen et Jiang, 1981 and G. nila limbaticollis Chen et Jiang, 1981, having prothorax narrowly margined with fulvous and legs entirely fulvous. Very possibly these two subspecies might be united.

Geinella ?krishna Maulik, 1936

MATERIAL. China, Tibet, Gyoze La E Damxung, 30³5'47"N, 9129'58"E, 4650 m, leg. J. Schmidt, 2 ex. (MNE, LM).

REMARK. Was described from Xizang (Tibet).

Hymenesia tranquebarica (Fabricius, 1798)

REMARK. A series of beetles ( 9 ex.) was collected in Tamil Nadu (India) on Euphorbia (Canthium) parviflorum. A food plant was not known earlier.

\section{Subfamily Alticinae}

Argopistoides septempunctata Jacoby, 1892

MATERIAL. China, S. Yunnan (Xishuangbanna), $23 \mathrm{~km} \mathrm{NW}$ Gunghong, vic. Na Ban (NNNR), N 2209.49', E 100³9.92', 730 $\mathrm{m}$, rubber plantation, MF, 12.V.2008, leg. A. Weigel, 11 ex.
REMARK. Distributed in South China, Vietnam, Thailand, Myanmar, Singapore, but firstly found in Yunnan. This genus often cited as Torodera Weise, 1902 or Parathrylea Duvivier, 1892

\section{Manobidia antennata Chen, 1934}

MATERIAL. China, S. Yunnan (Xishuangbanna), $23 \mathrm{~km} \mathrm{NW}$ Junghong, vic. Na Ban (NNNR), N 22 $09.49^{\prime}$, E 100³9.92', 730 m, transitional zone, MF-1, 10.X.2008, leg. A. Weigel, 3 + + (NME, 1 ex. - LM).

REMARK. Well corresponds to the original descriptions, but antennae not modified; it seems that described type specimens are males.

\section{Hyphasis fedorenkoi L. Medvedev, 2009}

Fig. 7.

MATERIAL. New Vietnam, Lao Cai Prov., Hoang Lien NP, Tram Ton, N 22²1'20", E 10346'51', 1800-2500 m, 15.V.2015, leg. A. Weigel, 2 우 (NME, LM); N. Vietnam, Lao Cai Prov., Hoang Lien NP, Tam Ton, N 22²1'197”, E 10346'513”, 1800-2050 m, 13-16.V.2015, leg. A. Scale, 1 क (NME).

REMARK. Seems to be identical with $H$. fedorenkoi $\mathrm{L}$. Medvedev, 2009, described also from Hoang Lien Shon. A single known specimen (male) of $H$. fedorenkoi has entirely black antennae and red head, its size is however $5.9 \mathrm{~mm} .3$ females cited above have entirely black head and rather large size $(7.3-7.4 \mathrm{~mm})$. Spermatheca — Fig.7.

\section{References}

Chen S.H., Jiang S.Q. 1981. Coleoptera: Chrysomelidae, Galerucinae // The series of the comprehensive scientific expedition to the Quingai-Xizang. Vol.1. Peking: Sciences press: P.457-489 Medvedev L.N. 2006. Contribution to the knowledge of the genus Chrysolampra Baly, 1859 (Coleoptera, Chrysomelidae, Eumolpinae) from Indochina // Entomologica Basiliensia. Vol.28. P.154-161. 